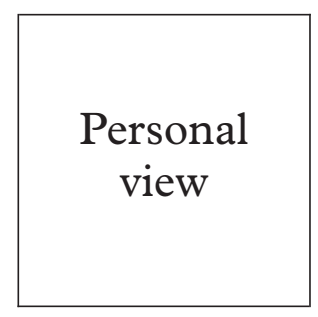

\section{Shimo la Mungu}

"God's Hollow" at the edge of Tanzania's Makonde Plateau is right up there when it comes to natural beauty spots. Its clear, unpolluted air yields views of hundreds of miles to the next kopje. Miombo woods of exquisite horticultural beauty clothe the escarpment which is too steep to allow browsing herds or woodcutters. The air is cleaved by squadrons of sleek, needle tailed, amazingly aerobatic varieties of hirudines hawking myriad clouds of butterflies and other insects. Above majestic eagles soar and disport.

Fifteen years ago I was working for a voluntary organisation in a local government hospital, I slightly despised the "Bwana Kubwa" who occasionally passed by on various safaris. Once I found they had negligently discarded imported food into Shimo la Mungu. In their air conditioned vehicles they seemed out of touch.

I was reasonably competent in Kiswahili. It was by no means the first above knee plaster of paris that I had applied to a young boy suffering the occupational accident of falling from a mango tree. If I said something as simple as: "Rudi kama inauma" (come back if it hurts), the meaning should have come across. It was a typically busy day. There were crocodile bites and obstructed labours and cerebral malarias and all the glorious panoply of doctoring in the bush. When the boy's father brought him back some 10 days later, I honestly could not remember what I had said to them after putting on that plaster.

His quite incredible and quite characteristic bravery at first misled me as to the graveness of his case. OK, so the toes certainly were a bit cold — especially for a hot day — and a bit black even for the Makonde race . . .. Only as I started to inch back the plaster bit by bit with the simple tools that were all we had, and despite his spartan heroism, the boy could not hold back his cries of agony, did the awful result of my intervention become plain. The stench was terrible even by the extremes commonly encountered in such contexts. Beneath the discoloured plaster, no living tissue remained. A grisly amputation in a fetid theatre was the only therapeutic option.

This patient changed my practice; thereafter I would insist upon admitting all such fracture cases for 24-48 hours after applying the plaster of paris to make sure that the circulation was not compromised during the early phase of tissue swelling. Bed occupancy was no problem, extras just joined the other outliers on the floor once all the available bed space had been filled.

But this change was too late to help that boy. Life is hard enough for the Makonde even with both legs. Just to fetch water they will often have to walk five or six miles each day. $\mathrm{He}$ recovered well postoperatively but if he survives today, he must be an accomplished beggar, Iimagine.
When hail fellow folk cajole me upon the faux pas of my career, I can usually keep my sense of humour; the remembrance of other unhappy cases have mostly been laid to rest. Some victims even forgave me themselves like the good natured woman whose rectum my episiotomy repair suture encircled. After her three days of constipated torment, never again did the inexperienced SHO neglect that unpleasant final PR examination on the labour ward! Others' suffering was put to a different use. The unfortunate patient who died with bilateral subdural haematomas as a result of a myelogram even furnished a brief report to the effect of the dangers of this investigation.

But you, poor Tanzanian child, though I shrive you to the page, the horror of your immense iatrogenic suffering will not be exorcised.

Fifteen years later, I have become a "Bwana Kubwa" myself. My Department For International Development (DFID) co-consultant and I are met at the airport of another sub-Saharan African country by a convoy of armoured landrovers. It calms our anxieties but must eat into the $0.27 \%$ of British GNP devoted to overseas aid.

We lecture (on HIV), inspect facilities, discuss projects, are entertained hospitably. Next week a larger DFID consultancy arrives, lectures, inspects, and is entertained. The $0.27 \%$ is eroded further.

Fifteen years ago, the organisation now known as DFID supported salaries of doctors and other aid workers who lived out in places as remote as Shimo la Mungu for years. Now, no one is supported for years. Consultants come and go. The proportion of DFID's budget devoted to administration has more than doubled.

In the past 15 years, the poorest $20 \%$ of the world have got $20 \%$ poorer; their mean income is now one fifty-ninth of that of the richest $20 \%$. Tanzania was one of the poorest countries in the world even 15 years ago. The Makonde Plateau, for all its beauty, had no water. The first daily task of the district medical officer was to try to borrow a bowser or a vehicle to drag it or some petrol to fuel it to fetch some water to enable the hospital to function. (A task which he performed with untiring and inspiring good humour and tenacity.)

Yet despite its poverty, drugs were dispensed free at Tanzanian government hospitals 15 years ago. Patients were also fed. There were blankets on the beds. This was before the IMF structural adjustments. In the country I now visit (and probably throughout Africa) none of these most basic items is free. Many patients default, for example, halfway through their treatment for tuberculosis, encouraging relapse and drug resistance. Many, many more do not get treated at all. 
The latest epidemic to strike Africa, HIV, is predicated upon the prevalence of genital tract infections. Without these, HIV infectivity is low and the epidemic spreads slowly (as in most western countries). Treatment for these infections, like all medical treatment, is now "income generating" under structural adjustment. Thus, the IMF programme has contributed to this epidemic.

During my lecture, I touch on the bizarre "lipodystrophy" seen in some patients taking the new combination antiretrovirals, in which subcutaneous fat is lost from the extremities and laid down centrally, I am struck by the likeness of the habitus with a diagram comparing world incomes arranged in quintiles which appeared in "Editor's choice" (BMF 10 April 1999).

Do the ineradicable experiences (which must befall most doctors during the course of our life's work) colour our world view? Swallows glide magnificently through the clear

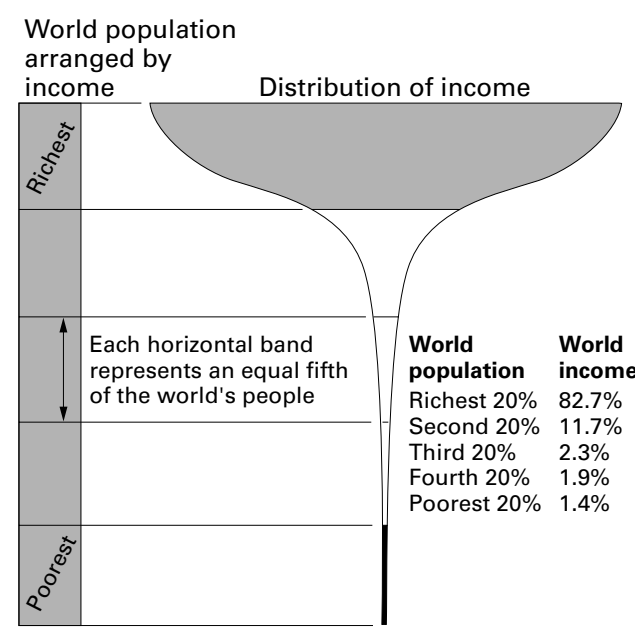

air of Shimo la Mungu; life's tougher for the insects they prey on.

HUMPHREY BIRLEY Liverpool, UK

\section{Balham chronicles}

\section{With a pinch of salt}

"Rob, I know you're a doctor-can I have a word about your son." The reception class nursery nurse's words chilled me to the bone, as Jamie (aged 5) had been off colour for a few days. "I am a bit worried about the rash he has got on his face. Three other children in the class have a similar rash-do you think it is infectious?"

I looked at the bright red rash on his cheeks and, despite struggling for some time, no diagnosis came to mind and an embarrassing silence followed.

"Well ..... . I don't think it is infectious."

"We need a doctor's letter to say that it is okay for Jamie to be at school."

"I do infectious diseases-hang on I've got some headed paper in my bag, I'll write a note now."

"No! We need a letter from a proper doctor-could you get a letter from his GP."

A call on my mobile phone secured an urgent appointment with the GP. When we arrived the practice receptionist asked if we minded seeing the locum. Time was of the essence and I readily agreed. Walking into the locum's room I was greeted by the wife of our research registrar. After a full history (three days of malaise, feeling feverish and sweaty, a rash had appeared) and a thorough examination (there was nothing to find), she turned to me and said, "Well, I don't know what the rash is-do you?"

A letter for the school was quickly drafted, it read "I have seen Jamie Miller and I have also consulted an infectious disease consultant (surely not me?). We both agree Jamie is not infectious and may return to school."

Armed with the letter I returned to school with Jamie. As I handed over the letter the nursery nurse seemed somewhat surprisedparticularly as I learned that two more children in his class now had similar rashes. Jamie was delighted to be back among his friends.

That evening, Jamie was running around the house chasing his sister-dressed only in his socks and pants. The doorbell rang, a close friend (a dermatologist) had arrived for a coffee. Standing on the doorstep she eyed up Jamie. "He's got erythema infectiosum ${ }^{\star}$-I'm not coming in-he's infectious!"

Now where are those revalidation documents from the GMC?

Balham, London SW12 87P

ROB MILLER

^Erythema infectiosum, erythema of the cheeks with a slightly raised margin, giving the appearance of a slapped cheek, this is raised margin, giving the appearance of a slapped cheek, this is
due to parvovirus B19 infection. Erythema infectiosum is also known as fifth disease or slapped cheek syndrome. 